${ }^{\circledR}$ Entomologica Fennica. 19 June 1996

\title{
Population densities and diversity of Noctuidae (Lepidoptera) along an air pollution gradient on the Kola Peninsula, Russia ${ }^{1}$
}

\author{
Mikhail V. Kozlov, Jukka Jalava, Alexandr L. Lvovsky \& Kauri Mikkola
}

Kozlov, M. V., Jalava, J., Lvovsky, A. L. \& Mikkola, K. 1996: Population densities and diversity of Noctuidae (Lepidoptera) along an air pollution gradient on the Kola Peninsula, Russia. - Entomol. Fennica 7:9-15.

The noctuid moths were monitored by means of bait traps from 1991 to 1993 in the area polluted by the Severonikel smelter on the Kola Peninsula. The total catch was 869 specimens belonging to 21 species. The catches peaked in sites representing the earlier stages of forest decline, being about two times as large as in the unpolluted area. The noctuid moths were heterogeneous in their response to pollution impact: (1) Xestia rhaetica, X. speciosa and Eurois occultus showed a clinal decline towards the emission source, (2) Diarsia mendica peaked at slightly polluted sites, (3) Acronicta auricoma, Hyppa rectilinea, Apamea maillardi and Xestia alpicola were most abundant in moderately polluted areas, (4) a mountain tundra species, Polia conspicua, was collected in heavily polluted sites only. However, neither species richness nor diversity of Noctuidae were affected by pollution.

Mikhail V. Kozlov, Laboratory of Ecological Zoology, University of Turku, FIN-20014, Finland

Jukka Jalava \& Kauri Mikkola, Zoological Museum, P. O. Box 17, FIN00014 University of Helsinki, Finland

Alexandr L. Lvovsky, Department of Entomology, Zoological Institute, 199034 St. Petersburg, Russia

Received 26 November 1993, accepted 16 March 1996

\section{Introduction}

Although aerial pollution represents one of the major factors of environmental disturbance (Freedman 1989), the effects of air-borne emissions on animal biodiversity are still poorly documented (Newman et al. 1992). The majority of field studies of insects in polluted zones have been aimed at revealing changes in density and/or performance of certain species rather than the response of insect communities to pollution of their habitats. Because reactions of insects to pollutants can be species- or group-specific (Kozlov 1990a, Heliövaara \& Väisänen 1993), pollution may lead to modification of species assemblages and therefore to changes in species richness and diversity (Armentano \& Bennett 1992, Newman et al. 1992, Kozlov in press).

The Noctuidae are relatively large, generally night-active moths. The fauna of the noctuid moths of the boreal forests worldwide amounts to nearly

${ }^{1}$ Report no. 2 from the research project on Entomological Bioindicators on the Kola Peninsula. 
two hundred species. At the northern tree limit in Finnish Lapland, about 60 species have been recorded (Koponen et al. 1982), and about the same number of species (58) was reported from the Kola Peninsula (Kozlov \& Jalava 1994). These moths (except some of the day-active species) can be easily collected in the bait traps which became popular during the last few decades. Bait traps have been used in faunistic and ecological investigations (Koponen \& Linnaluoto 1983) and in environmental monitoring programs (Mikkola 1975, Kuussaari et al. 1990). These traps are of special importance in northern areas, where bright nights decrease the catches of light traps.

\section{Materials and methods}

\subsection{Study site}

The study was conducted near Monchegorsk, Murmansk district (Kola Peninsula, Northwestern Russia, $68^{\circ} \mathrm{N} 33^{\circ} \mathrm{E}$ ), in the area polluted by the Severonikel smelter. The aerial emissions consisting mostly of $\mathrm{SO}_{2}$ and heavy metals (Ni, Cu, Co) influence an area of ca. $10000 \mathrm{~km}^{2}$; industrial barrens occupy ca. $200 \mathrm{~km}^{2}$, and industrially dwarfed birch woodlands cover ca. $450 \mathrm{~km}^{2}$. The southern border of the visible effects on vegetation lies 50 to $60 \mathrm{~km}$ from Monchegorsk. Coniferous forests have vanished within a distance of 10 to $15 \mathrm{~km}$ from the smelter (for more details, see Kryuchkov 1993, Kozlov \& Haukioja 1995).

Moths were sampled in 14 localities, up to $65 \mathrm{~km}$ from the smelter (Fig. 1). The localities were classified according to level of the pollution-induced deterioration following the results of DECORANA ordination of the phytosociological data (Koroleva 1993 and pers. comm.). Two localities (1 km both $\mathrm{N}$ and $\mathrm{S}$ of the smelter) represented heavily damaged secondary birch forests, with spots of ruderal vegetation (zone 4). Sites 5, 9 and $15 \mathrm{~km} \mathrm{~S}$ of the smelter represented birch transitional communities (zone 3). Sites located 11 and $13 \mathrm{~km} \mathrm{~N}$ of the smelter were chosen in sparse pine forest, whereas sites 17,19 and $21 \mathrm{~km} \mathrm{~S}$ of the emission source represented sparse spruce forests (zone 2). Slightly weakened spruce forests were studied in three sites situated 23, 29 and $35 \mathrm{~km} \mathrm{~S}$ of the smelter (zone 1). From 1991 to 1992, the most distant site was $29 \mathrm{~km}$ $\mathrm{S}$ of the smelter. But in the course of our study, we recognized that this site represented not healthy but slightly weakened forest (zone 1), and therefore in 1993 we additionally chose in sites $35 \mathrm{~km} \mathrm{~S}$ (zone 1) and $65 \mathrm{~km}$ SSE of the smelter as clean controls (zone 0).

The mean ambient concentrations of sulphur dioxide in our sites were measured in 1994 by passive lead-dioxide absorbers (the method described by Barkan 1993), whereas the foliar concentrations of $\mathrm{Ni}$ were estimated by $\mathrm{X}$-ray fluorescence (Kozlov et al. 1995) (Table 1).

\subsection{Trapping}

The bait traps (construction described by Jalas 1970) were in operation 28.6-29.7.1991, 26.6-8.8.1992 and 8.7-12.8.1993. The lure was prepared from beer, concentrate of bread "kvass", malt, sugar, honey and jam, fermented by ordinary yeast. To promote odour distribution, the traps were hung on separate trees at a height of 2 to $3 \mathrm{~m}$, two to five traps per study site. They were emptied each third

Table 1. Pollution loads in zones of pollution-induced forest deterioration and basic characteristics of moth samples.

\begin{tabular}{ccccccrr}
\hline $\begin{array}{c}\text { Zone Foliar Ni } \\
\mathrm{mg} / \mathrm{kg}\end{array}$ & $\begin{array}{c}\text { Ambient } \mathrm{SO}_{2} \\
\mu \mathrm{g} / \mathrm{m}^{3}\end{array}$ & $\begin{array}{c}\text { No of } \\
\text { species }\end{array}$ & $\begin{array}{c}\text { No of } \\
\text { specimens }\end{array}$ & $\begin{array}{c}\text { Total abundance } \\
\text { exx/traps } \times \text { night }\end{array}$ & $\begin{array}{c}\text { No of species } \\
\text { per 15 exx" }\end{array}$ & $\begin{array}{c}\text { Shannon-Weaver } \\
\text { diversity index }\end{array}$ \\
\hline 0 & $14 \pm 2$ & $2.3 \pm 0.1$ & 9 & 51 & $0.49 \pm 0.12$ & $5.48 \pm 1.05$ & 1.70 \\
1 & $46 \pm 5$ & $52.7 \pm 12.6$ & 12 & 457 & $0.89 \pm 0.14$ & $3.59 \pm 1.02$ & 1.00 \\
2 & $70 \pm 8$ & $55.3 \pm 18.5$ & 12 & 197 & $0.61 \pm 0.12$ & $4.75 \pm 1.09$ & 1.58 \\
3 & $146 \pm 21$ & $129.3 \pm 26.9$ & 12 & 148 & $0.42 \pm 0.08$ & $4.62 \pm 1.16$ & 1.42 \\
4 & $250 \pm 78$ & $159.8 \pm 7.8$ & 6 & 16 & $0.07 \pm 0.02$ & $5.99 \pm 1.05$ & 1.49 \\
\hline
\end{tabular}

"Nickel concentration measured in leaves of Betula pubescens subsp. tortuosa (Ledeb.) Nyman; means for 1991-1993 (after Kozlov et al. 1995). "Rarefaction-corrected values 
Fig. 1. Study area and position of sampling sites; numbers denote zones of pollution-induced forest deterioration. Insert: position of study area in the Kola Peninsula.

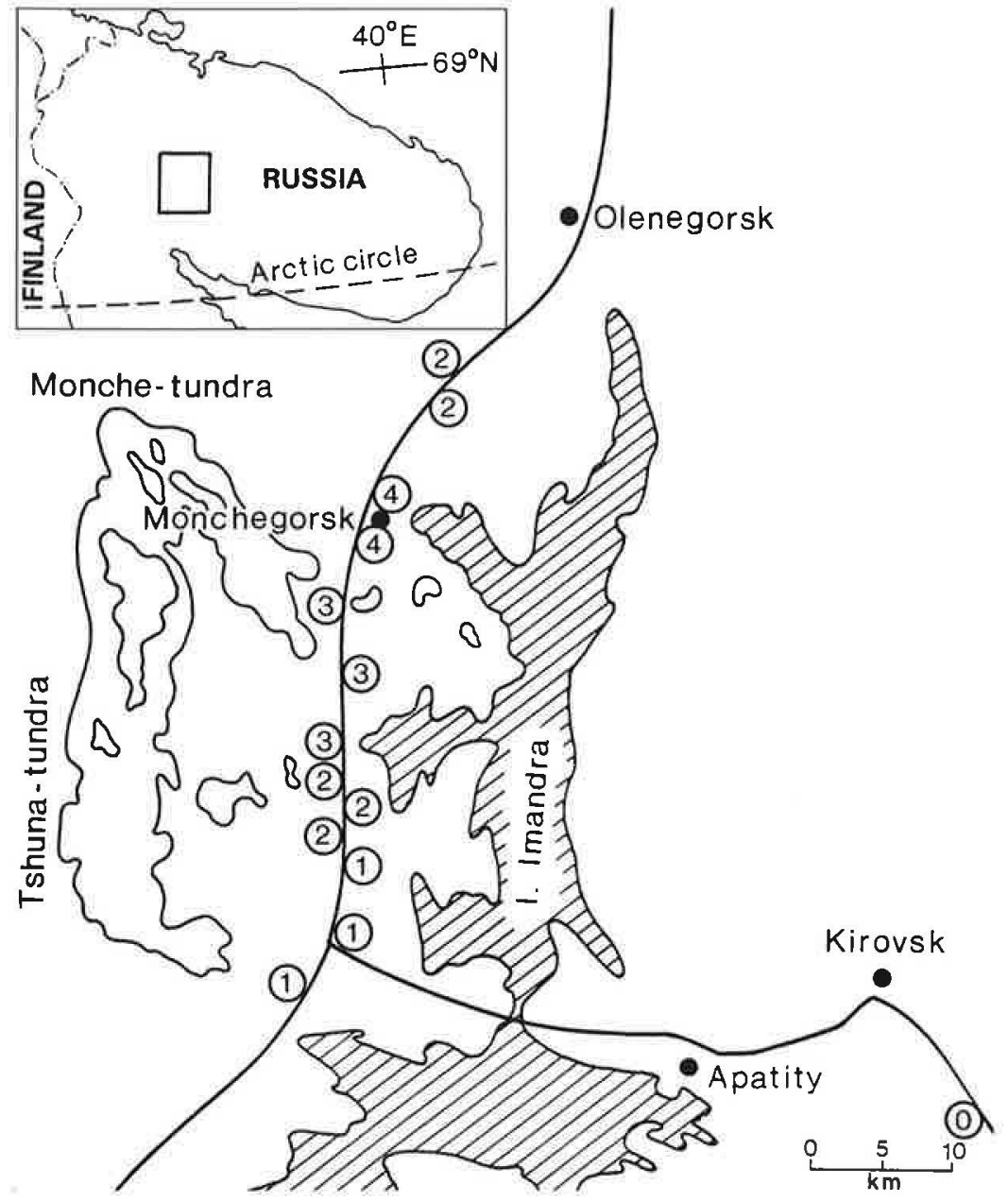

to fifth day. In order to keep the catches of different traps comparable, the lure was changed on the same day in each trap. All moths (except some specimens damaged by ants) were pinned. The material is preserved in the Zoological Museum in Helsinki.

\subsection{Data analysis}

The abundance of moths (exx/trap*night) calculated for each trap-emptying was tested by the SAS NPAR1WAY procedure with the year of collection, site and vegetation ranking as independent variables. Pairwise differences between the zones of vegetation disturbance were revealed by a Kruskal-Wallis test (SAS Institute 1990). Species richness was analyzed for the pooled data of 19911993. Effects of the sample size were assessed by comparison of the number of recorded species with the value expected from rarefaction (Heck et al. 1975, Sokal \& Rohlf 1981). Diversity was measured as the Shannon-Weaver index; correlations were calculated by the SAS CORR procedure (SAS Institute 1990).

\section{Results and discussion}

\subsection{Population densities}

In total, 869 specimens representing 21 species were collected (Table 2). Among them, Diarsia mendica was the most abundant (515 exx, about $61 \%$ of total); 5 species were common (25-126 exx), 3 species infrequent (14-18 exx), 4 species rare $(2-5$ exx $) ; 8$ species were represented by a 
single specimen. Because the among-year variation in total catch (calculated for the localities studied in all three years) was not significant $\left(\mathrm{F}_{2,114}=0.72\right.$, $P=0.49$ ), the hypothesis of pollution impact on the moth abundance and diversity was tested by use of the pooled data of 1991-1993.

Diarsia mendica was the only species sufficiently abundant to allow an application of reasonable statistical analysis of densities. For other species, only the trends in mean densities can be discussed.

The variation in density of $D$. mendica among vegetation zones (Fig. 2) was highly significant $\left(F_{4,240}=7.34, P<0.0001\right)$. The maximum density observed at sites with zone 1 was seven times as high as the background level (zone 0). Pairwise comparisons between pollution zones showed that the differences in densities of $D$. mendica were significant between zones 0 and 1,1 and 2, 3 and 4 , and insignificant between zones 2 and 3 .

The densities of four species (A. auricoma, $H$. rectilinea, $A$. maillardi, $X$. alpicola) peaked in the moderately polluted (zone 2) areas (Fig. 2), being 2.5 to 5 times higher than the clean control.

Quite surprisingly, the 38 specimens of $P$. conspicua, a mountain tundra species, were collected at the border of the industrial barrens (zone 3 ) and even in the immediate vicinity of the smelter (Fig. 2). The occurrence of Apamea remissa only in the heavily damaged birch woodlands is probably explained by the appearance of the ruderal Poaceae in areas where the primary ground layer vegetation had vanished. None of the species was recorded exclusively in the zone 4.

Three species (Xestia rhaetica, X. speciosa, $E$. occultus) demonstrated a clinal decrease in their

Table 2. Results of trapping.

\begin{tabular}{|c|c|c|c|c|c|c|c|c|c|c|c|c|c|c|c|c|c|}
\hline \multirow[t]{3}{*}{ Species } & \multicolumn{17}{|c|}{ Number of specimens collected at different distances $(\mathrm{km})$} \\
\hline & \multicolumn{3}{|c|}{$\begin{array}{l}\text { Total specimens } \\
\text { collected in the year }\end{array}$} & \multicolumn{7}{|c|}{ to the North } & \multicolumn{7}{|c|}{ to the South } \\
\hline & 1991 & 1992 & 1993 & 13 & 11 & 1 & 1 & 5 & 9 & 15 & 17 & 19 & 21 & 23 & 29 & 35 & 65 \\
\hline Acronicta aunicomaD.\&S. & 37 & 0 & 1 & 1 & 0 & 2 & 0 & 1 & 3 & 5 & 7 & 0 & 9 & 1 & 9 & 0 & 0 \\
\hline Enargia paleacea Esp. & 0 & 2 & 3 & 0 & 0 & 0 & 0 & 1 & 0 & 0 & 2 & 0 & 0 & 0 & 1 & 1 & 0 \\
\hline Parastichtis suspectaHb. & 0 & 0 & 1 & 0 & 0 & 0 & 0 & 0 & 0 & 0 & 0 & 0 & 0 & 0 & 0 & 0 & 1 \\
\hline Hyppa rectilineaEsp. & 7 & 1 & 17 & 0 & 0 & 1 & 0 & 4 & 0 & 1 & 8 & 0 & 1 & 2 & 4 & 3 & 1 \\
\hline Apamea crenata Hufn. & 0 & 1 & 0 & 0 & 0 & 0 & 0 & 0 & 1 & 0 & 0 & 0 & 0 & 0 & 0 & 0 & 0 \\
\hline Apamea lateritia Hufn. & 0 & 1 & 0 & 0 & 0 & 0 & 0 & 0 & 0 & 0 & 0 & 1 & 0 & 0 & 0 & 0 & 0 \\
\hline Apamea maillardiGeyer & 0 & 9 & 5 & 0 & 0 & 1 & 0 & 0 & 1 & 0 & 4 & 5 & 0 & 1 & 2 & 0 & 0 \\
\hline Apamea remissa $\mathrm{Hb}$ & 2 & 4 & 0 & 0 & 0 & 0 & 0 & 6 & 0 & 0 & 0 & 0 & 0 & 0 & 0 & 0 & 0 \\
\hline Hillia ins Zett. & 0 & 1 & 0 & 0 & 0 & 0 & 0 & 0 & 0 & 0 & 0 & 0 & 0 & 0 & 1 & 0 & 0 \\
\hline Mniotype adustaEsp. & 2 & 0 & 1 & 0 & 0 & 0 & 0 & 0 & 0 & 1 & 1 & 0 & 0 & 1 & 0 & 0 & 0 \\
\hline Polia conspicuaB.-H. & 13 & 0 & 25 & 0 & 0 & 4 & 0 & 33 & 1 & 0 & 0 & 0 & 0 & 0 & 0 & 0 & 0 \\
\hline MelanchrapisiL. & 0 & 1 & 0 & 0 & 0 & 0 & 0 & 0 & 0 & 0 & 1 & 0 & 0 & 0 & 0 & 0 & 0 \\
\hline Papestra biren Goeze & 2 & 0 & 0 & 0 & 0 & 0 & 0 & 0 & 0 & 0 & 0 & 0 & 0 & 0 & 2 & 0 & 0 \\
\hline Cerapteryx graminis L. & 0 & 0 & 1 & 0 & 0 & 0 & 0 & 0 & 0 & 0 & 0 & 0 & 0 & 0 & 0 & 1 & 0 \\
\hline DiarsiamendicaF. & 201 & 225 & 89 & 4 & 1 & 6 & 1 & 62 & 11 & 9 & 39 & 4 & 25 & 105 & 198 & 35 & 15 \\
\hline Xestia haetica Stgr. & 8 & 28 & 17 & 0 & 0 & 0 & 0 & 0 & 0 & 0 & 0 & 0 & 1 & 1 & 37 & 0 & 14 \\
\hline Xestia speciosa Hb. & 5 & 0 & 13 & 0 & 0 & 0 & 0 & 5 & 0 & 0 & 1 & 0 & 0 & 0 & 0 & 0 & 12 \\
\hline Xestia distensa Ev. & 0 & 0 & 1 & 0 & 0 & 0 & 0 & 0 & 0 & 0 & 0 & 0 & 0 & 0 & 0 & 0 & 1 \\
\hline Xestia laetabilisZett. & 0 & 0 & 1 & 0 & 0 & 0 & 0 & 0 & 0 & 0 & 0 & 0 & 0 & 0 & 0 & 0 & 1 \\
\hline Xestia alpicolaZett. & 6 & 48 & 72 & 13 & 4 & 1 & 0 & 1 & 0 & 0 & 46 & 10 & 2 & 2 & 20 & 24 & 3 \\
\hline Eurois occultusL. & 0 & 12 & 6 & 1 & 0 & 0 & 0 & 1 & 1 & 0 & 2 & 3 & 1 & 0 & 5 & 1 & 3 \\
\hline Effort (traps $\times$ nights) & 538 & 790 & 440 & 93 & 68 & 134 & 84 & 286 & 103 & 62 & 200 & 67 & 74 & 105 & 332 & 70 & 90 \\
\hline Species & 10 & 12 & 15 & 4 & 2 & 6 & 1 & 9 & 6 & 4 & 10 & 5 & 6 & 7 & 10 & 6 & 9 \\
\hline Specimens & 283 & 333 & 253 & 19 & 5 & 15 & 1 & 114 & 18 & 16 & 111 & 23 & 39 & 113 & 279 & 65 & 51 \\
\hline $100 \times$ specimens/effort & 53 & 42 & 58 & 20 & 7 & 11 & 1 & 40 & 17 & 26 & 56 & 34 & 53 & 108 & 84 & 93 & 57 \\
\hline Zone of vegetation & - & - & - & 2 & 2 & 4 & 4 & 3 & 3 & 3 & 2 & 2 & 2 & 1 & 1 & 1 & 0 \\
\hline
\end{tabular}



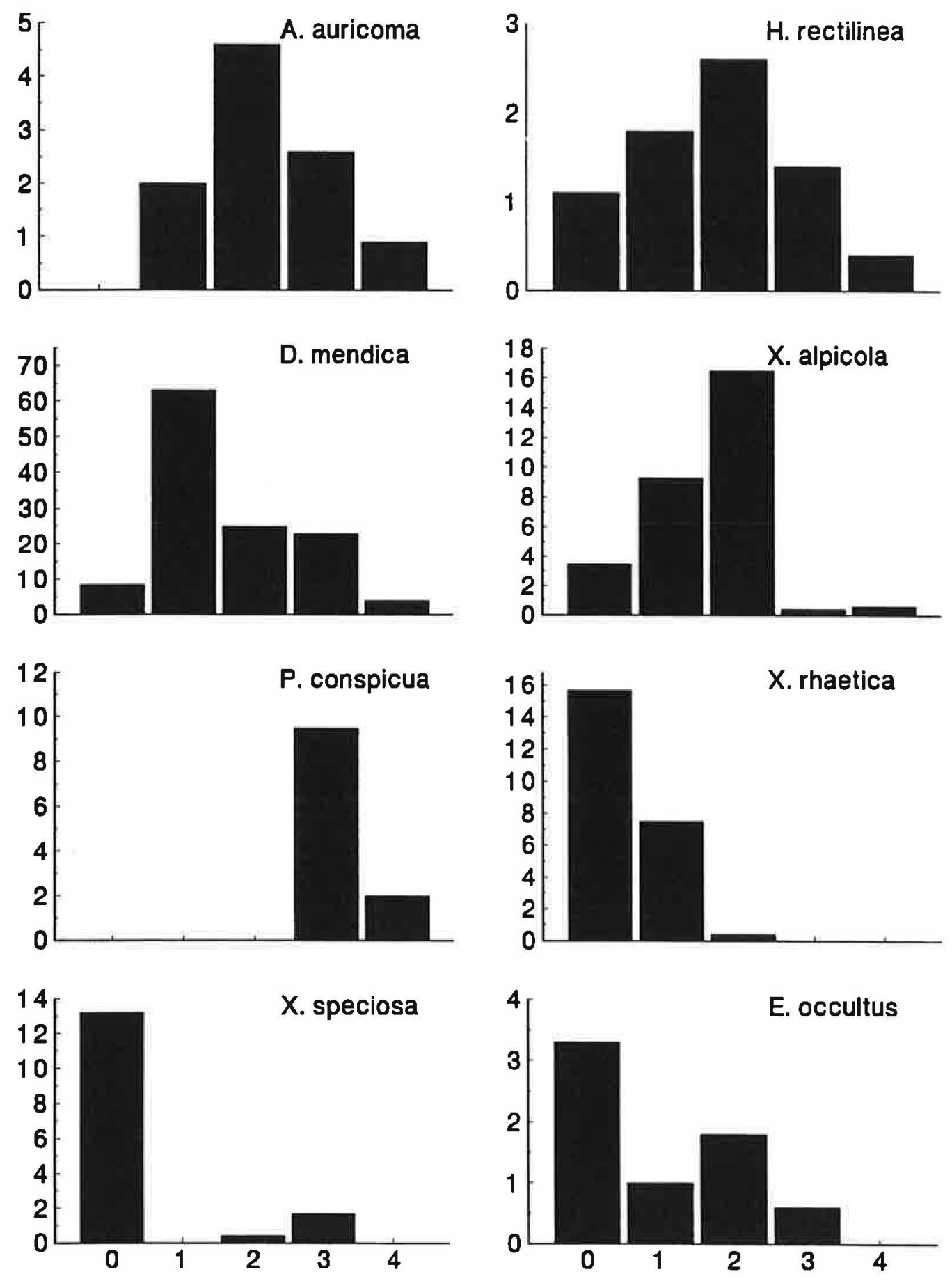

Fig. 2. Mean catch of noctuid moths $(100 \times$ exx/trap $\times$ night $)$ classified according to zones of forest deterioration. 
densities towards the emission source (Fig. 2). This type of density pattern seems to be quite rare among Lepidoptera: it has been reported only for lichenfeeding Nolidae and Lithosiidae, in which the caterpillars are deprived of any food in the polluted areas (Grosser 1980, Tietze 1980). However, larvae of these three species feed on plants which are quite abundant even in the immediate vicinity of the smelter (Vaccinium, Solidago, Betula, Salix), and therefore the density decrease could not be attributed to the decrease in food supply.

Noctuid moths are heterogeneous in their reactions to effects of aerial pollution, and thus both species composition and abundance changed along the pollution gradient. However, since there exists a strong causal relationship between pollution load and habitat deterioration, it is impossible to attribute these changes to any certain pollutant or habitat characteristic.

Among Lepidoptera, increase in ecological densities (i.e. specimens per food supply) in the heavily and/or moderately polluted areas seems to be the type of situation (Kozlov 1990b) explained by changes in host-plant quality (Koricheva \& Haukioja 1992). Our data showed that population densities (i. e. specimens per area) of some noctuids also peaked at moderate pollution loads, although these peaks corresponded to lower pollution loads than did the peaks in the ecological densities of some microlepidopterans (M. Kozlov, personal observations). We can suppose that in contrast to the miners and leafrollers (which are more or less protected from the acid rains), the direct negative effects of acidification may be more important for caterpillars feeding on the leaf surface.

\subsection{Abundance, species richness and diversity}

The total abundance of noctuid moths in sites representing the earliest steps in pollution-induced modification of the spruce forest (zone 1) was significantly (Kruskal-Wallis test: $\chi_{1}^{2}=18.24, \mathrm{P}<0.0001$ ) higher than in the clean control site (zone 0 ). Towards the emission source, density decreased steeply, falling to $10 \%$ of the background level in heavily polluted localities (Table 1).

Pairwise comparison showed that differences in moth abundance between zones 2 and 3 were not significant $\left(\chi_{1}^{2}=2.06, \mathrm{P}<0.15\right)$, while both pri- mary forests (zone 0 ) and industrial barrens (zone 4) differed significantly from the neighbouring zones $\left(\chi_{1}^{2}=9.77\right.$ and $16.1, \mathrm{P}<0.0018$ and 0.0001 , respectively).

The lower numbers of species in both the completely destroyed and the primary communities are probably related to the small sample sizes more than to changes in species richness: the rarefactioncorrected values for species richness (Table 1) did not correlate with mean ambient $\mathrm{SO}_{2}$ concentrations $(r=0.29, n=5, P=0.63)$. Similarly, the Shannon diversity index based on three-year samples of Noctuidae did not correlate with $\mathrm{SO}_{2}$ concentrations $(r=-0.11, n=5, P=0.86)$. Thus, our data contradict the general consensus that polluted habitats display reduced diversity (Magurran 1988), but agree with results of surveys of Lepidoptera in subalpine habitats affected by the Severonikel smelter (Kozlov 1996).

\section{Conclusions}

Aerial emissions influence both the species composition and abundance of Noctuidae. Six of the nine species represented by a statistically sufficient number of specimens demonstrated their maximum densities within the polluted area. The densities of four species peaked in the moderately polluted area (vegetation zone 2); one species had its peak in the slightly polluted (zone 1) and one in the heavily polluted (zone 3 ) area. Three species showed clinal decline towards the emission source. Total catches of Noctuidae peaked at the earliest stages of forest deterioration, which was mostly caused by the maximum densities of Diarsia mendica. We failed to discover any effects of pollution on species richness or diversity of Noctuidae.

Acknowledgements. We thank E. Halme, L. Svetsova and V. Zverev for their assistance in the data collection, E. Zvereva for fruitful discussions, and E. Haukioja and an anonymous referee for valuable comments on earlier drafts of the manuscript. The study was supported by the Academy of Finland through a grant to K. Mikkola.

\section{References}

Armentano, T. V. \& Bennett, J. P. 1992: Air pollution effects on the diversity and structure of communities. 
— In: Barker, J. R. \& Tingey, D. T. (eds.): Air pollution effects on biodiversity. - Van Nostrand Reinhold, New York, pp. 159-176.

Barkan, V. Sh. 1993: Measurement of atmospheric concentrations of sulphur dioxide by passive lead dioxide absorbers. - In: Kozlov, M. V., Haukioja, E. \& Yarmishko, V. T. (eds.): Aerial pollution in Kola Peninsula. - Proc. Intern. Workshop, April 14-16, 1992, St. Petersburg, pp. 90-98.

Freedman, B. 1989: Environmental Ecology. The impact of pollution and other stresses on ecosystem structure and function. - Academic Press, New York, 424 pp.

Grosser, N. 1980: Industrielle Imissionen und Bioindication durch Lepidopteren im Gebiet der Dübener Heide. Wiss. Beitr. Univ. Halle. 28:63-67.

Heck, K. L., van Belle, G. \& Simberloff, D. 1975: Explict calculation of the rarefaction diversity measurement and the determination of sufficient sample size. Ecology 56:1459-1461.

Heliövaara, K. \& Väisänen, R. 1993: Insects and pollution. - CRC-Press, Florida, 393 pp.

Jalas, I. 1970: Perhostenkeräilijän opas. — Otava, Helsinki, $268 \mathrm{pp}$.

Koponen, S., Laasonen, E. M. \& Linnaluoto, E.T. 1982: Lepidoptera of Inari Lapland, Finland. - Kevo notes, 6:1-36.

Koponen, S. \& Linnaluoto, E. T. 1983: Colour morphs of Hillia iris (Lepidoptera, Noctuidae). - Not. Ent. $63: 177-81$

Koricheva, J. \& Haukioja, E. 1992: Effects of air pollution on host plant quality, individual performance, and population density of Eriocrania miners (Lepidoptera: Eriocraniidae). - Environm. Entomol. 21:1286-1292.

Koroleva, N. 1993: Pollution-induced changes in forest vegetation structure as revealed by ordination test. In: Kozlov, M. V., Haukioja, E. \& Yarmishko, V. T. (eds.): Aerial pollution in Kola Peninsula. - Proc. Intem. Workshop, April 14-16, 1992, St. Petersburg, pp. 339-345.

Kozlov, M. V. (Козлов, М. В.) 1990a: [Impact of anthropogene factors on the populations of terrestrial insects] - VINITI, Moscow. 192 pp. (In Russian)

- 1990b: The ecology of Lepidoptera in forests suffering from air pollution. - In: XIX IUFRO World Congress, 5-11, August 1990, Montréal, Canada. Proceedings, Div. 2:151.

- 1996: Subalpine and alpine assemblages of Lepidoptera in the surroundings of a powerful smelter on the Kola Peninsula, NW Russia. — Nota lepidopterologica 18 : 17-37.
- in press: Pollution impact on insect biodiversity in boreal forest zone: evaluation of effects and possibilities of recovery, - In: Crawford, R. (ed.): Disturbance and recovery of Arctic terrestrial ecosystems: Proceedings of NATO Advanced Research Workshop, 24-30 September 1995, Rovaniemi, Finland.

Kozlov, M. V. \& Haukioja, E. 1995: Pollution-related environmental gradients around the "Severonikel" smelter complex on Kola Peninsula, Northwestern Russia. - In: Munawar, M. \& Luotola, M. (eds.): The contaminants in the nordic ecosystem: the dynamics, processes and fate. - Ecovision World Monograph Series, S. P. B. Academic Publishing, The Netherlands, pp. 59-69.

Kozlov, M. V., Haukioja, E., Bakhtiarov, A. V. \& Stroganov, D. N. 1995: Heavy metals in birch leaves around a nickel-copper smelter at Monchegorsk, Northwestem Russia. — Environ. Pollut. 90:291-299.

Kozlov, M. V. \& Jalava, J. 1994: Lepidoptera of the Kola Peninsula, northwestern Russia. - Entomologica Fennica 5: 65--85.

Kryuchkov, V. V. 1993: Degradation of ecosystems around the "Severonikel" smelter complex. - In: Kozlov, M. V., Haukioja, E. \& Yarmishko, V. T. (eds.): Aerial pollution in Kola Peninsula. - Proc. Intern. Workshop, April 14-16, 1992, St.Petersburg, pp. 35-46.

Kuussaari, M., Mikkola, K. \& Vakkari, P. 1990: [Industrial melanism of moths as an air quality indicator in the Helsinki Metropolitan Area: years 1988-1989] (in Finnish, English abstract). — Pääkaupunkisedun julkaisusarja C 1990:3, 17 pp.

Magurran, A. E. 1988: Ecological diversity and its measurement. — Chapman \& Hall, London, 197 pp.

Mikkola, K. 1975: Frequencies of melanic forms of Oligia moths (Lepidoptera, Noctuidae) as a measure of atmospheric pollution in Finland. - Ann. Zool. Fennici 12:197-204.

Newman, J. R., Schreiber, R. K. \& Novakova, E. 1992: Air pollution effects on terrestrial and aquatic animals. In Barker, J. R. \& Tingey, D. T. (eds.): Air pollution effects on biodiversity. - Van Nostrand Reinhold, New York, pp. 177-233.

SAS Institute 1990: SAS/Stat. User's guide, version 6.0 . — SAS Institute, Cary, N.C. 1686 pp.

Sokal, R. R. \& Rohlf, F. J. 1981: Biometry. 2nd ed. W.H.Freeman \& Co. New York, 859 pp.

Tietze, F. 1980: Tierische Organismen als Bioindikatoren zur Erfassung ökologischer Veränderungen in imissionsbeeinflußten Ökosystemen. - Wiss. Z. Univ. Halle-Wittenberg. Math. — Naturw. R. 29 (5) :83-93. 